\title{
GEOMETRIC PRIMITIVES ASSESSING ITALIAN-CZECH VAULT CONSTRUCTION TECHNIQUES IN BAROQUE PERIOD
}

\author{
C. Stanga ${ }^{2}$, H. Hasníková ${ }^{3}$, R. Brumana ${ }^{1}$, A. Grimoldi ${ }^{2}$, F. Banfi ${ }^{1 *}$ \\ ${ }^{1}$ Dept. of Architecture, Build Environment and Construction Engineering, Politecnico di Milano, Milan, Italy - \\ (fabrizio.banfi; raffaella.brumana)@polimi.it \\ ${ }^{2}$ Dept. of Architecture and Urban Studies, Politecnico di Milano, Milan, Italy - (alberto.grimoldi; chiara.stanga)@polimi.it \\ ${ }^{3}$ Institute of Theoretical and Applied Mechanics, Czech Academy of Sciences, Czech Republic -hasnikova@itam.cas.cz
}

\section{Commission WG II/8, WG III/5, WG V/1}

KEY WORDS: Grade of generation (GOG), SCAN-to-BIM, Geometric primitives, Vault construction techniques, Baroque period

\begin{abstract}
:
The developments of the latest technology in the field of Digital Cultural Heritage (DCH) are revolutionizing the methods of surveying, representing and managing the built heritage. The integrated use of $3 \mathrm{D}$ survey instruments such as laser scanning, digital photogrammetry and the new holistic way to represent the architecture, based on the Building Information Modeling (BIM), allows the collection, analysis and archiving of a large amount of data, by increasing information sharing among a great number of experts involved during the life cycle of the building. The paper focuses on the connection between Italy and Czech in terms of vaults patterns and construction techniques. The two case studies are the frame vault of the chapel of the Italian Cultural Institute and the barrel vault with lunettes of the Klementinum Baroque Library. They are both unique examples of the great expertise of architects and craftsmen that worked in Bohemia across the $17^{\text {th }}$ and $18^{\text {th }}$ centuries. Most of them were from the North of Italy, like the ones that worked in the building sites of the two case studies. The in-depth study of the construction techniques and the complex shapes needs the use of new scan-to-BIM modeling requirements, based on the definition of geometric primitives useful for the generation of intelligent threedimensional models able to integrate different types of data. Finally, the acquired data are included in a database that collects information coming from both Italian and Czech studies, raising awareness among citizens of the richness of their built heritage.
\end{abstract}

\section{INTRODUCTION}

In recent years, technological developments in the field of the 3D survey have allowed professionals, such as architects, historians, and engineers to obtain a large amount of data useful to digitally analyse the built heritage. The main tools such as laser scanning and digital photogrammetry have made it possible to considerably reduce the traditional phases of the direct survey and increase the data acquisition of the detected artefacts from a typological and morphological point of view. The main outputs of these technologies are 3D scans, commonly known as point clouds, from which it is possible to extract coordinates and measurements from every single point. On the other hand, these data still require a re-elaboration process, based on the transformation of points into intelligent digital models, to which it is possible to associate different types of information such as wall stratigraphy, physical parameters, mechanical and historical data, thus embedding the tangible and intangible values of the artefacts. This process is known as Scan-to-BIM, which allows the transformation of geometric primitives (points and wireframe models) into building information modeling (BIM) that corresponding to the detected reality. Once models have been created, information mapping can improve the transformation of the 3D scans in complex BIM objects such as historic vaults, irregular and damaged walls, managing the new paradigm of complexity (Brumana et al., 2018a; Banfi et al., 2017).

The article focuses on the analysis of the construction techniques of the vaults from the Baroque period in Prague and the connection with Italian builders' knowledge. The spread of Italian builders, coming from the Northern areas, over the Alps, has already been analyzed in the literature (Della Torre et al., 1997). The authors of the presented paper try to understand what it means in terms of construction knowledge and technique sharing. The study involves two vaulted systems in Prague, the Klementinum Baroque Library and the Italian Cultural Institute chapel (Fig. 1). They offer the possibility to compare construction similarities and differences of two variations of the barrel vault typology. Both vaults were built to span spaces characterised by an emphasized longitudinal axis. They are also excellent examples of the great Baroque decorations, the Klementinum Baroque Library vault with the illusionistic painting and the Italian Cultural Institute chapel vault with its precious stuccos. The vaults were built in the same time frame, the end of the $17^{\text {th }}$ century and the first half of the $18^{\text {th }}$ century, and their building sites involved Italian builders at different levels. In order to detect the construction techniques of the vaults, a photogrammetric survey was performed (intrados and extrados). Thanks to a novel SCAN-to-BIM process based on the integrated use of different grades of generation (GOG) (Banfi, 2017), it has been possible to generate accurate models, showing the level of complexity of the detected structures. The goals of the research are:

- To show the Italian-Czech relationship, already described as the sharing of knowledge and builders, in terms of constructive techniques;

- To document the vaults by non-invasive and quick survey methods;

- To develop a proper workflow for the generation of accurate HBIMs that capture the geometrical complexity of the vaults;

- To find a balance between the geometric complexity of the vaults, the data acquired and the 3D representations.

\footnotetext{
* Corresponding author
} 


\section{HISTORICAL-GEOGRAPHICAL CONTEXT}

It is since the late 1520 s that the migration of Italian architects and builders from the North of Italy to Bohemia has started to increase considerably (Franchetti Pardo, 2002). In the Modern Age, the Bohemian architecture acquired the stylistic features of French and Italian baroque architecture (Norberg-Schulz, 1968). In particular, it assimilated all the nuance of the Italian maniera that were developed in peculiar centres, like Rome, Milan, Genoa, and Venice, and it introduced innovative elements that were later brought to Italy (Uličný, 2014). Scholars have already correlated the work of important architects, such as Dientzenhofer, Santini, and Hildebrandt with the stylistic features of Italian baroque architects, like Borromini and Guarini (Norberg-Schulz, 1968; Pavlík, 1994). Further analysis can help to understand how the construction knowledge of the Italian builders developed in Prague: if and how the builders' knowledge merge with the local construction culture and techniques and what were the main references in handbooks and manuals. The vaulted systems, presented in the paper, are interesting examples to analyse this knowledge exchange. Italian architects were involved at different levels in the building sites of the two case studies. In particular, the chapel in the Italian Cultural Institute presents an integration between the Italian and Czech constructive techniques for the realization of the vault and the roof structure.

\section{RELATED WORKS}

The understanding of vaults construction techniques has been a topic of interest both in Italian and Czech literature. In Czech, researches started from the study of vaults typologies and construction processes (Lipanská, 1999), then moved to the detailed analysis of specific case studies in the Modern Age, with the particular attention to the construction techniques (Škabrada 2007) and the geometrical-material surveys with digital instruments and representations (Svorník, 2007). In Italy, the literature mainly concentrates on precise geographical areas and vault typologies (Manuali del recupero). Manuali are an operative tool for architects and engineers in the restoration sites, so they give a global knowledge of the construction techniques and simplify the complexity of the historical buildings, made of stratification of historical phases and combination of different techniques. That is why, in recent years, different efforts were carried out to correlate the understanding of the construction processes with the detailed 3D surveys and representations (Brumana et al., 2017) offering a wider picture of the vaults historical and geographical wide-spreading (Grimoldi, 2009, Brumana et al., 2018a). The understanding of a vault construction is not only interesting from a historical point of view (the materials used, the scaffolding type, the vault typology, etc.), but it is also necessary for the preservation of the built heritage at least for two main reasons. First of all, it allows keeping alive the skills of the craftsmen, which reflects the technical culture of that time, strong intangible value of the built heritage. It is crucial now more than ever since it is hard to find masons able to reproduce the traditional knowledge. Moreover, it is not so common to find a correspondence between the case study and the literature (treatises) because very often it was not necessary to explain everything in the handbooks since craftsmen knew how to do the construction of the vaults (Wendland, 2005). Secondly, the clear understanding of a vault construction leads to a better interpretation of its structural behaviour and allows to perform more responsible restorations. From a methodological point of view, the paper is related to the research carried out on the vaulted system in the North of Italy, which aims at the understanding of the construction techniques through a novel scan-to-BIM digital workflow (Brumana et al., 2017). In this case, the 3D model is essential to understand the complex geometries and construction techniques that are hidden behind the apparently simple shape of a vault intrados (Brumana et al., 2018a).

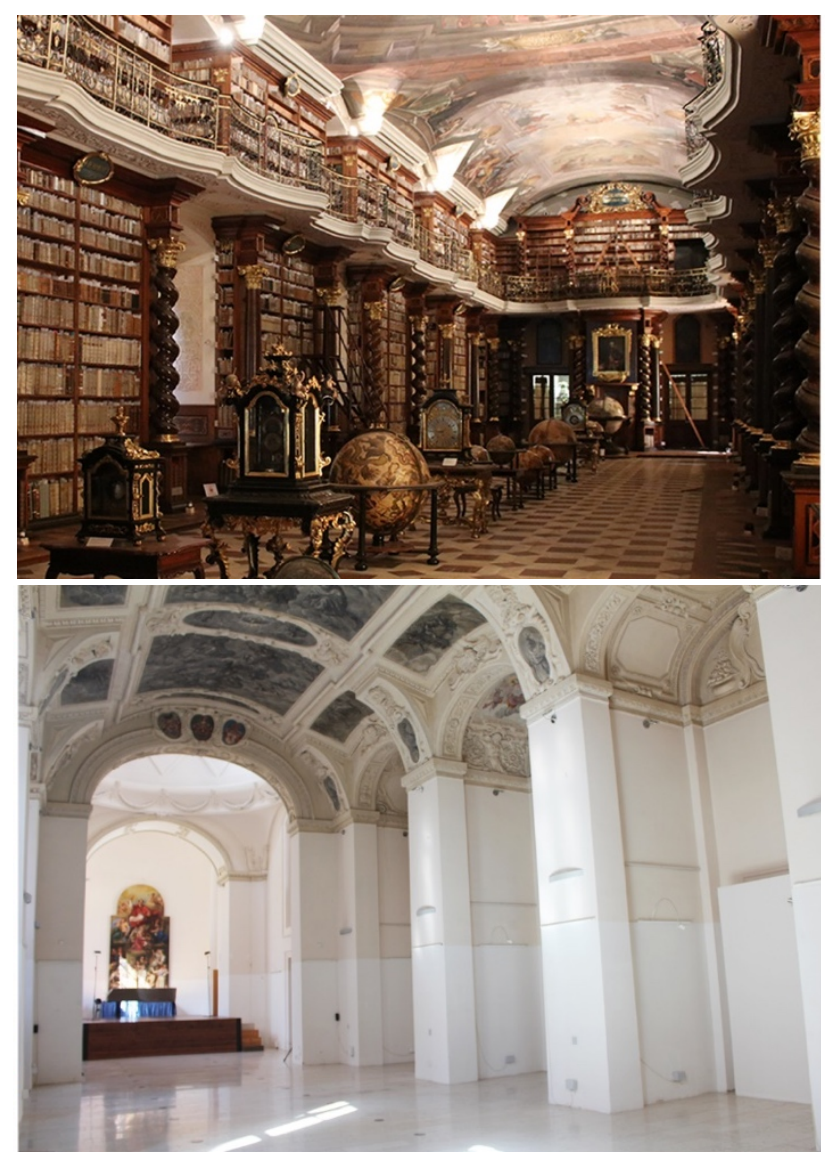

Figure 1. The Klementinum Baroque Library (top) and the Italian Cultural Institute (bottom)

\section{METHODOLOGY OF THE RESEARCH}

The methodology adopted for the research is based on four steps: the collection of the existing literature (4.1), the photogrammetric survey (4.2), the data acquired during the in situ visits (4.3), and the data post-processing necessary to develop the $3 \mathrm{D}$ models (4.4).

\subsection{Collection of the existing literature}

A general overview of the Bohemian baroque architecture cannot avoid the study of the works of important art historians and critics, like Swoboda and Norberg-Schulz (Swoboda, 1964; Swoboda, 1981; Norberg-Schulz, 1968, Norberg-Schulz, 1982), together with the analysis of the Italian-Czech connections (i.e. Horyna and Líbal, 1987; Franchetti Pardo, 2002; Graciotti and Křesálková, 2003). Many Italian builders were involved in the building sites and although literature about the exchange of knowledge between Italian and Bohemian exists (Della Torre et. al., 1997 - just to name one), it is still difficult to connect the name of one architect to a specific construction site due to the lack of the documentation and records from the past. What can be done further, and today is still missing, is to carry out more extensive studies on the buildings realized by Italians architects in order to compare their constructive and stylistic features (Kofroňová, 2003). 


\subsection{Photogrammetry}

Photogrammetry has been a suitable low-cost and quick method, appropriate for the survey of the two case studies.

The Klementinum pictures dataset was gained with Canon EOS $80 \mathrm{D}$ camera, focal length $32 \mathrm{~mm}$, placed on the rectangular grid of $750 \times 1300 \mathrm{~mm}$. In this case, the camera was placed parallel to the ground, other images were taken from the balcony in order to capture the lunettes, a total of 423 pictures were acquired.

For the Italian Cultural Institute chapel, two cameras were used. The intrados and cupola sets were realized with Canon EOS 600D, while two sets for extrados parts were made with Canon EOS-1D Mark IV camera. The focal length was $28 \mathrm{~mm}$ for both the chapel intrados and cupola. The intrados needed 343 pictures to be taken (including the ones taken from the matroneo), in the rectangular grid of $750 \times 1300 \mathrm{~mm}$. For the cupola, 43 pictures were taken with the camera placed parallel to the ground. Two sections (spans no. 2 and no. 3) of the chapel were photogrammetrically surveyed for extrados; the focal length for both of them was $35 \mathrm{~mm}$. The surfaces had to be cleaned from the dust so that the desired brick texture was visible. The photogrammetric block has 233 pictures (span no. 2), 207 pictures (span no. 3) respectively. The extrados parts were chosen because they represent two construction phases of the building: span no. 2 (the newer part) and span no. 3 (probably the oldest part) (Fig. 2). Agisoft Photoscan software was used to post-process the photogrammetric blocks. The datasets have been the basis for the realization of the orthomosaics, which are necessary to the material and decay analysis (cracks, imprints after water leakage, etc.), and for the point clouds that were used for the $3 \mathrm{D}$ model reconstructions. The models later help to understand better the structural behaviour and the construction technology of the vaults.

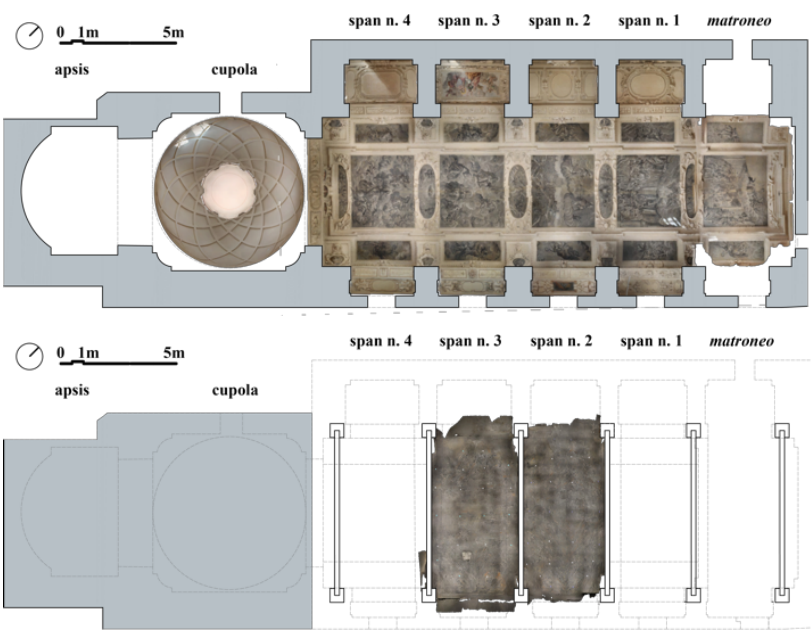

Figure 2. Orthomosaic of intrados (top) and extrados (bottom) of the Italian Cultural Institute chapel

\subsection{In situ data acquisition}

The two case studies represent different "boundary conditions" of the survey. The Klementinum vault was accessible only at the level of the intrados, while the Italian Cultural Institute chapel was accessible both at the intrados and the extrados.

The Klementinum Baroque Library space has many constraints due to the presence of old valuable books and frescoes. Therefore, any kind of instrumental analysis has to be carefully prepared and discussed, because the measurement must not change temperature and humidity environmental conditions and the presence of a high number of people for a long period might be a problem. Taking the data in the form of a photogrammetric block is an ideal way of how to do a pilot survey with a noninvasive method while collecting much information. Also, the basic dimensions of the room were measured with a laser dilatometer. The extrados of the vault is not accessible because in the 1930s a concrete slab was added above the Baroque Library during the restoration by architect Ladislav Machň, so that the capacity of the National Library was increased (Oulíková, 2006). To understand the construction technology of the vault, the analysis of the extrados is crucial and from the intrados, only some hypothesis can be carried out, that will be discussed later.

The Italian Cultural Institute chapel has a turbulent history. From its foundations up to the present days it was first a chapel, then it gradually became the part of a factory building, a school, and an orphanage. It was completely restored in the 1990s (see the reports of the restoration of the stuccos and the old trusses: Berger et al., 1999, Stirber et al., 1999) and today is used as a concert and exhibition hall. Because of public use, it is easy to visit intrados without any restrictions. In this case, together with the basic geometrical survey (trilateration), it was also possible to do photo documentation of both intrados and extrados. Not only the basic floor plan proportions were evaluated, but also the detailed analysis of the span no. 2 was done in order to carry out the cross-section drawing.

\subsection{Data post-processing}

At the beginning of the image post-process, the photogrammetric data block and the sets of pictures taken in situ were processed by Agisoft Photoscan software automatically to get the point clouds representing the $3 \mathrm{D}$ geometry of the vaults. The software allows to 'mask' the objects and obstacles that might cause inaccuracies. For instance, the balcony in the Klementinum Baroque Library would cover the parts of the vault close to the side walls in the orthomosaic and any deflection sign occurring there would be invisible.

Once the point clouds were ready to be used as the 3D model basis, they were imported into modeling software, Rhinoceros 6.0 , where the main geometry was established. After the descriptions of the two case studies, the 3D modeling will be explained in paragraph 5.3.

\section{CASE STUDIES}

The Klementinum Library is the part of the Jesuit College complex, situated next to the Charles Bridge in the historical centre of Prague, while the Italian Cultural Institute is located at Malá Strana, on the west side of the Vltava river close to the Prague Castle.

\subsection{The Klementinum Baroque Library}

The Klementinum was the first Jesuit college in Bohemia (Fig. 3 ). The building construction started in the first half of the $17^{\text {th }}$ century on a former Dominican monastery. Many Italian architects and builders were involved in the work, such as Carlo Lurago, Francesco Caratti and Giovanni Domenico Orsi (Oulíková, 2006). Other famous Baroque architects worked on the building site, like František M. Kaňka and K. I. Dientzenhofer.

The Library is a rectangular room (floorplan dimensions are approximately $40 \times 10 \mathrm{~m}$ ) covered by a skene barrel vault with twelve lunettes, which was decorated by Jan Hiebel. The construction of the building itself was carried out from 1724 to 1727 , as the final date is written on the inlay of the plinths of the stack columns at the southern entrance. As there are no signed drawings, recent literature refers to K. I. Dientzenhofer as the 
architect of the Library on the basis of the stylistic features of the room (Oulíková, 2006). It is certain that Hiebel, the artist that realized the astonishing illusionistic decoration of the vault, was one of the pupils of the Italian artist Andrea Pozzo.

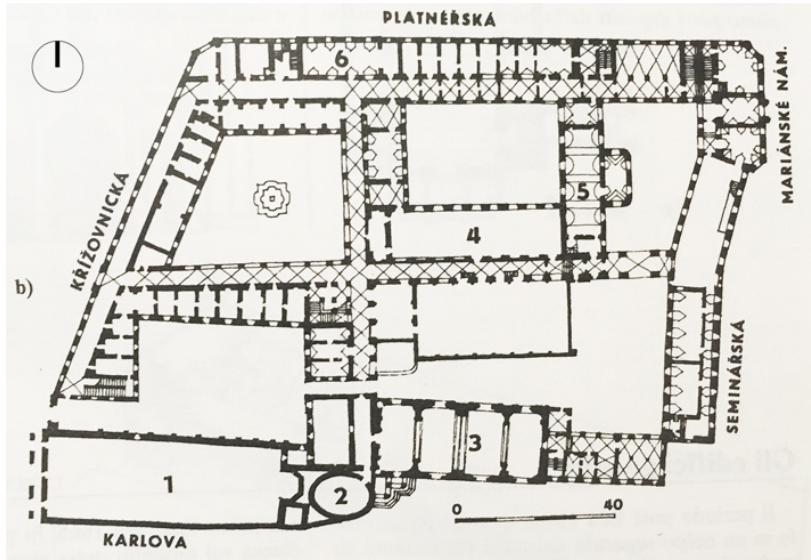

Figure 3. The Klementinum complex, room no. 4 refers to the Klementinum Baroque Library (Stankova, J., et al. 1991)

The decoration is divided into three fields: the central one with the illusion of a cupola (Fig. 4), while the other two have an architectural perspective that is opening on the sky. The same features can be seen in Andrea Pozzo's masterpiece decoration, the St. Ignazio church in Rome. The illusion of the cupola is the probable reason for the four lunettes of the central part of the vault to have a different shape at the intrados. The others have visible sharp edges when penetrating the central barrel, but these ones have a smoother passing (Fig. 5). The structural assessment of the vault was based on the photogrammetric data and 3D model. Uneven deflection close to the central part was discovered. There is a crack all along the longitudinal middle axis in the barrel vault (Fig. 6). These two observations were considered when making the hypothesis about the construction techniques of the barrel vault, as the extrados was not accessible.

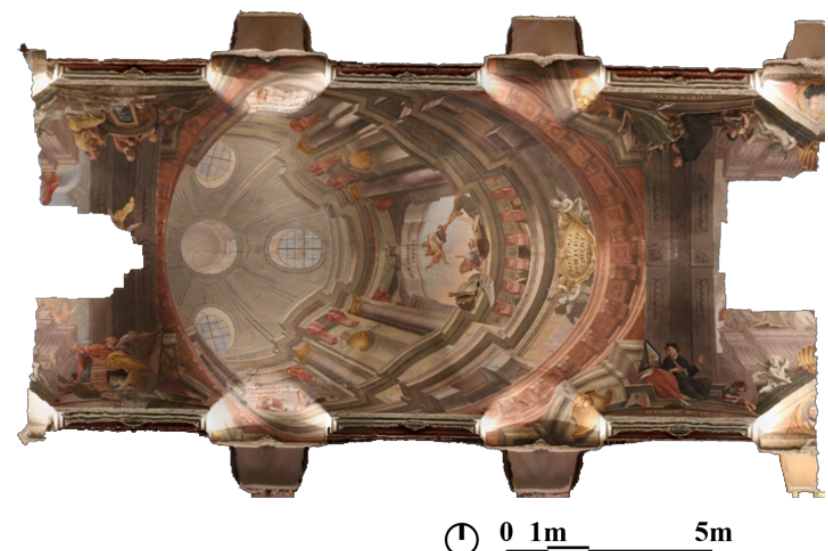

Figure 4. The illusionistic cupola at the vault intrados

The first reason for the structural problem can be the simple geometrical fact of the vault being very skene and with the longitudinal dimension around $40 \mathrm{~m}$. Another interpretation can be correlated to a possible loading from the roof structure that pushes on the walls of the building making the walls to moving on sides. As the roof space was not visited during the survey, the presence of possible tie rods, which could help the structural behaviour of the vault, cannot be confirmed. Previous damages in the roof can be assumed based on the old water leakage prints detected in the painting close to the deflected part of the vault. The third possible explanation of the deflection might depend on the vault construction techniques. Unfortunately, any specific traces were recognized, like arches, in the intrados. However, since the vault covers a very long and narrow room, it is very likely that masons realised extrados arches to carry out its construction. In that case, the crack and the deflection can be the consequence of any misalignments of the arches due to a different hardening of the mortars. In case there are not any extrados arches in the vault structure, the crack and deflection might come from the self-weight of the vault that is not supported by another stiffening structural element.

However, further analysis has to be done, because, during the onsite visit, it was even not possible to understand the crack width and if it affects only the plaster or the whole brick-block construction.
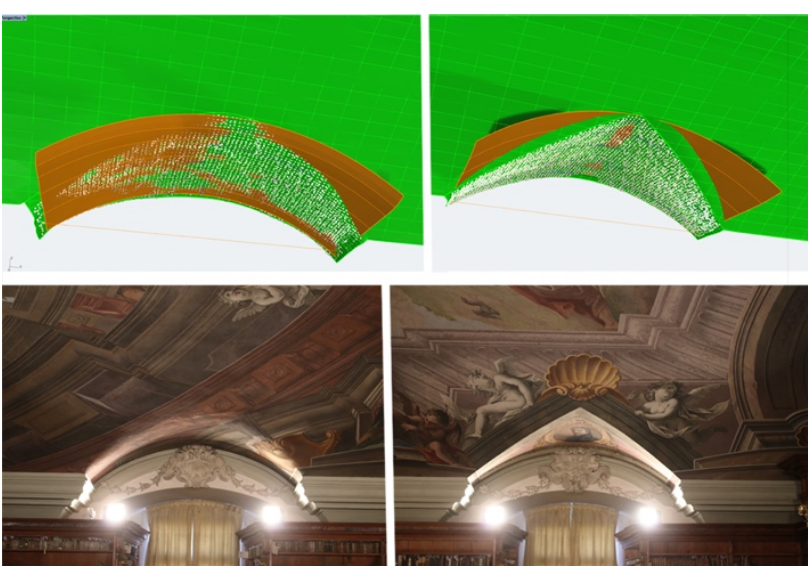

Figure 5. Comparison between the 'smooth' lunette of the illusionistic cupola (left) with the lunette of the other part of the vault (right). The orange represents the approximation of the shape of the 'smooth' lunette. The distance between the orange surface and the green one is around $5 \mathrm{~cm}$
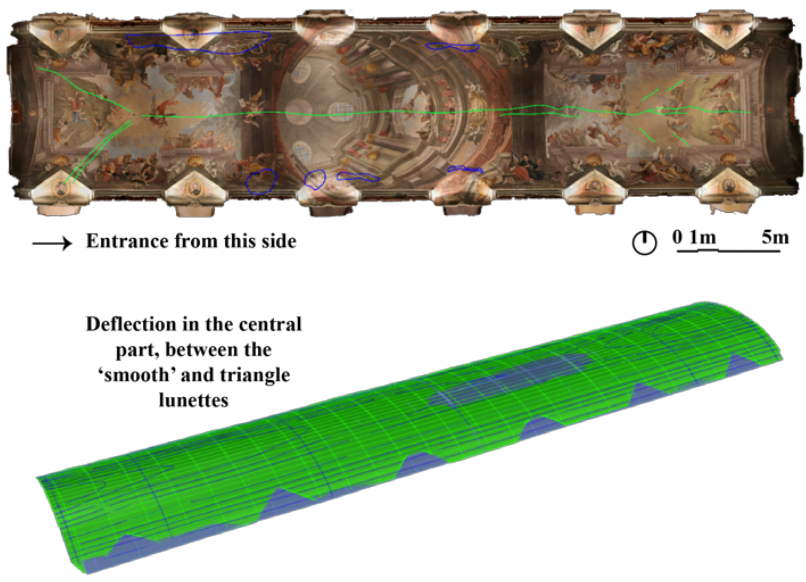

Figure 6. Crack patterns (green) and water leakages (blue) (top) and deflection analysis (bottom) of the Klementinum Baroque Library vault

\subsection{The Italian Cultural Institute in Prague}

The Italian Cultural Institute is established in the building complex that was realized around the beginning of the $17^{\text {th }}$ century as the hospital for the Italian community in Prague. The former chapel was extended around the first half of the $17^{\text {th }}$ century and dedicated to St. Carlo Borromeo and Virgin Mary (Fig. 7). The literature offers the names of many Italian builders 
that could be involved in the construction of the chapel, like Domenico Bossi who came from the Lugano and Como lake area (Kofroňová, 2003).

The chapel is formed by one nave $(20.5 \times 6.45 \mathrm{~m})$, covered by a frame vault, and two aisles with chapels covered by barrel vaults: the southern chapels are smaller than the northern ones. A square chevet covered by a cupola and an apsis close the space. The nave is made by 5 spans divided by pillars, which is the common layout of the early baroque Central Europe architecture (NorbergSchulz, 1968). Frame vaults are commonly widespread in Northern Italy since the late $16^{\text {th }}$ century (Grimoldi, 2009) and the Italian Cultural Institute chapel - finished around 1663-65 (Royt, 2003) - could be one of the examples of the typology in Prague. Another one is the vault, that covers the General Reading Room in the Klementinum College complex, which was built from 1669 by Italian builders Carlo and Francesco Lurago (Oulíková, 2006). The intrados of the Italian Cultural Institute chapel vault is covered by a homogeneous stucco and a painted decoration - one of the major examples of the early Baroque architecture in Prague (Royt, 2003). The extrados shows traces of different construction phases. As attested by the documents, the first demand to widen the building complex was in 1608, then the works were carried out again in 1643-44 (Kofroňová, 2003).

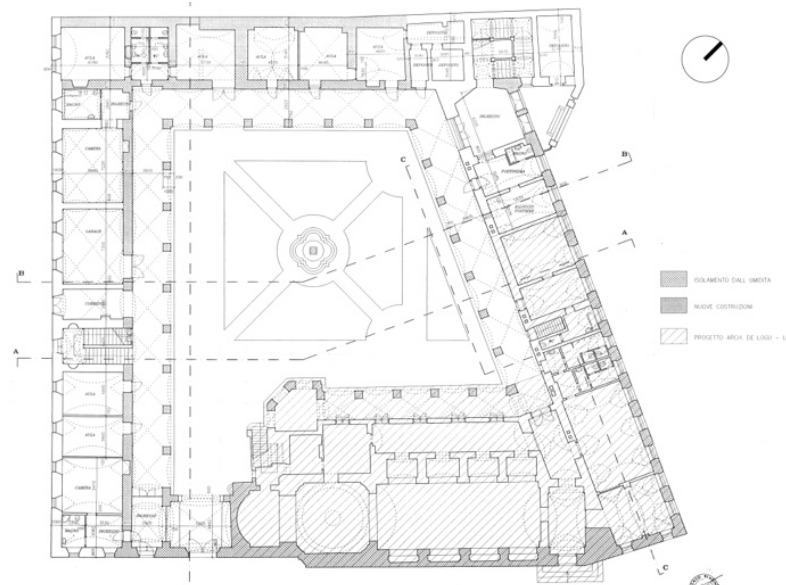

Figure 7. The Italian Cultural Institute complex with the chapel on the south-west side (courtesy of the Italian Cultural Institute).

It is highly possible that the described events are correlated with the traces found at the vault extrados: the two spans (no. 3, 4) close to the cupola present a different brick arrangements (soldier laid for the central skene barrel vault and diagonal arrangement for the side barrel vaults) from the other spans (diagonal brick arrangement for both the central skene barrel vaults and the side barrel ones) (Fig. 9).

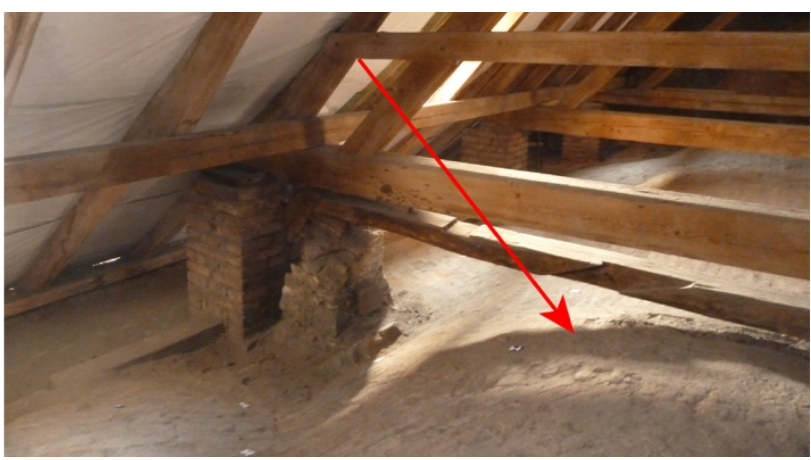

Figure 8 . The arch built at the end of the first construction phase

Also, there is an arch (Fig. 8) connecting the two differently brick arranged structures visible at the extrados - it could be the trace of the first phase of the building (beginning of $17^{\text {th }}$ century), which proofs that the other spans were built later. The construction process flow seems to happen in the following steps: the pillars dividing the aisles chapels were realized first, then the arches with brackets in between them (both the ones that span the chapels and the nave), later the roof structure, and finally the vaults.

span n. 3

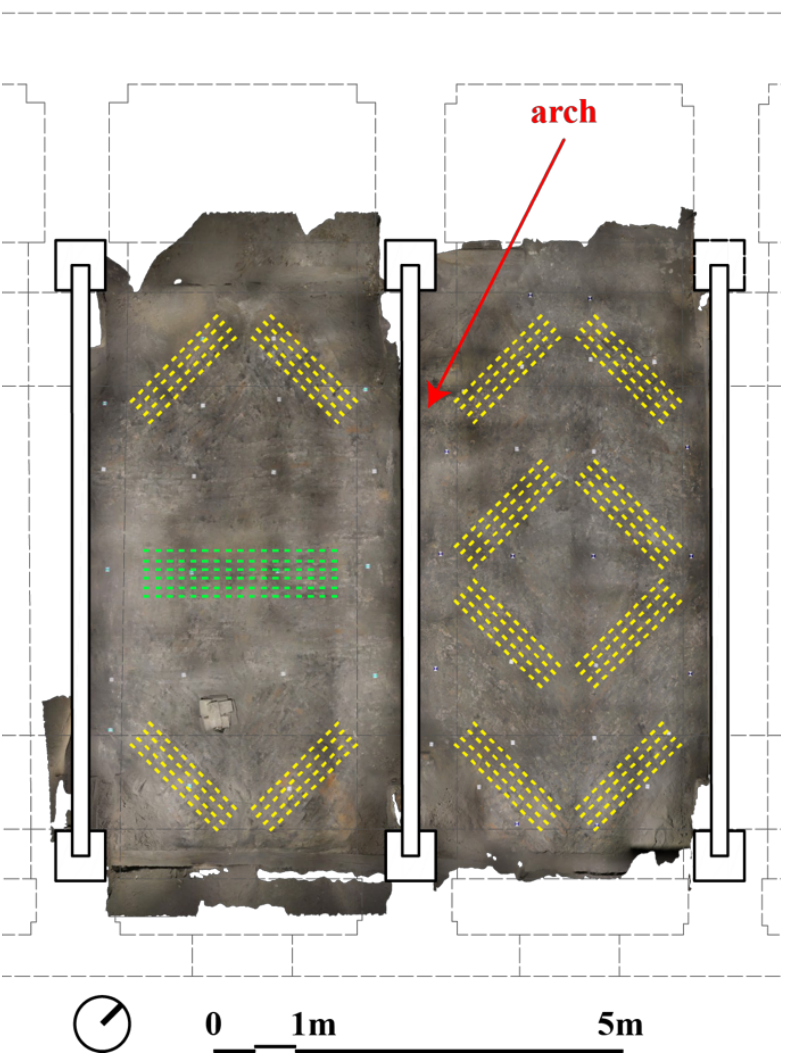

Figure 9. The orthomosaic of the extrados spans no. 2 and no. 3.

The same shape at the intrados corresponds to two different construction techniques: bricks arrange linear to the wall (green) and diagonal (yellow)

The arches with the brackets visible at the intrados help the construction of the vault by splitting the space to be covered. They were usually built with centerings, so that the vault webbing could be realized with a smaller centerings and light formworks or even by freehand technique.

Moreover, at the extrados of the older vault part, it is possible to see some traces of extrados arches in correspondence with the intrados arches. The arches can also serve as a kind of structural strengthening.

The current roof structure is not the original one, and it is a common Central Europe type - a purlin roof system with a simple ridge post (jednoduchá stojatá vaznicová stolice in Czech, Einfach Stehender Pfettendachstuhl in German; Vinař, 2010). Parts of the old trusses are preserved. Both the current and the old trusses are independent from the vault. However, two iron tie rods connecting the old timber tie beams and the vault in the newer part (matroneo, spans no. 1 and no. 2) were observed. It is a relatively typical way how to stiffen a vault; used during the Baroque period in Bohemia and well documented after the Thirty Years' War, which ended in 1648 (Škabrada, 2007). Also in Italy, 
metal and wooden tie rods are commonly used as part of the vault construction (Grimoldi, 2007).

The whole building presents some cracks. During the in situ observation of the chapel several cracks were detected: one vertical crack running from the vault to the wall of the northern side chapel no. 4 (an old one, monitored), three on the arches in between the southern side chapels no. 1, 2, 3, and one at the extrados of the no. 2 side barrel vault of the central part. The director of the Institute assumed that the cracks could be correlated to a small underground river flowing close to the building that has some influence on the foundation.

\subsection{The digital workflow applied to complex vaulted systems}

As mentioned in the introduction, the Scan-to-BIM process required a technique that properly extracts geometric primitives from point clouds for the generation of complex structural elements. The generative process provided for the integrated use of novel Grades of Generation (GOGs) 9 and 10. The level of complexity of both the vaults required the definition of geometric primitives able to represent the peculiarities with a grade of accuracy (GOA) of about $2 \mathrm{~mm}$.

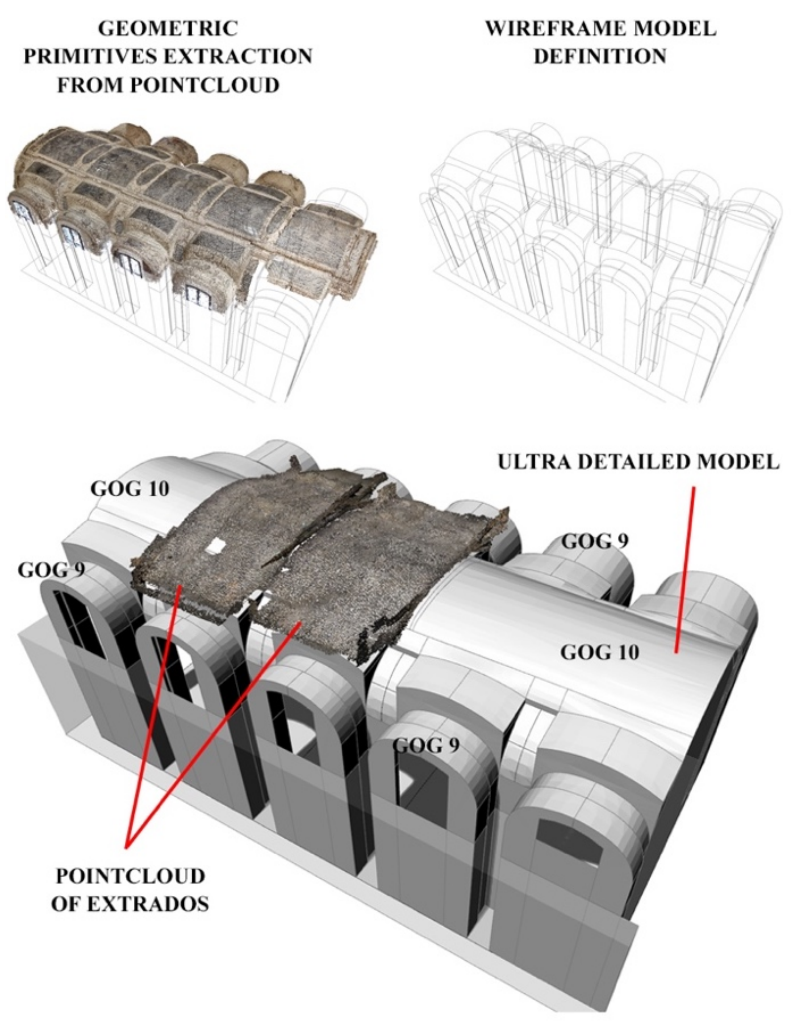

Figure 10. Digital Workflow of the vault 3D model of the Italian Cultural Institute with the indication of the parts realized by means of GOG 9 and GOG 10

The generative process envisaged the application of the GOG 9 for the definition of the geometric primitives corresponding to the external and internal edges of every single element (lunettes and vaults edges).

The GOG 10, on the other hand, allowed the application of NURBS algorithms based on direct interpolation of laser scanning points. This technique allowed a faithful 3D representation of the internal geometries of both vaults. Accordingly, the integrated use of the GOG 9 and ten have allowed to reduce the times and the generative costs of the HBIM models and to represent the three-dimensional reality with high precision values (Fig. 10). In order to verify the quality of both models, an automatic verification system (AVS) was applied to show the value corresponding to the standard deviation between the points and the model obtained and the curvature analyse (Fig. $11)$.

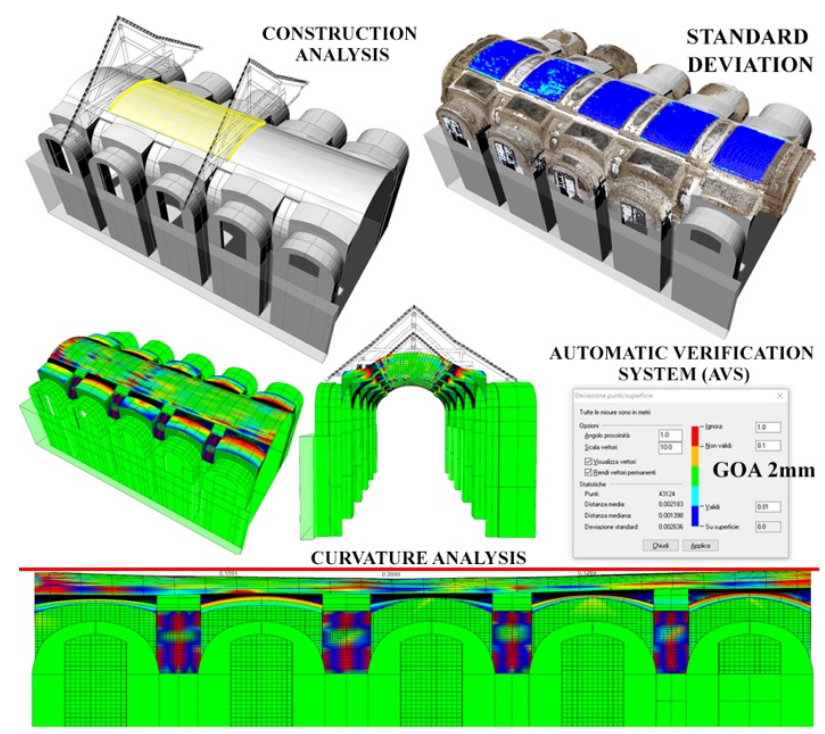

Figure 11. Automatic Verification System of the vault of the Italian Cultural Institute

\section{UNDERSTANDING THE CONNECTIONS BETWEEN ITALY AND THE CZECH REPUBLIC}

The two vaulted systems are great examples of the Baroque architecture in Prague. The barrel vault type is turned into two different variations: a barrel vault with lunettes for the Klementinum Baroque Library (with probable extrados arches) and a frame vault for the Italian Cultural Institute chapel.

The current arrangement of the Italian Cultural Institute chapel, with its nave and side chapels, recalls a typical "baroque nave with pillars", widespread in the south of Germany (NorbergSchulz, 1968). The churches with this floorplan arrangement were usually covered with sail or barrel vault with lunettes, but the one of the Italian Cultural Institute has a frame vault. From a construction point of view, the vault can be correlated rather with other frame vaults widespread in the North of Italy, from Brescia to Milan, and from Cremona to Mantua since the late $16^{\text {th }}$ century (Grimoldi, 2009). One example is the frame vault of the Refectory of San Sigismondo church in Cremona or the vaults that cover atrias in Turin (Spallone et al., 2017). Moreover, it is interesting to compare the Italian Cultural Institute chapel with other similar Bohemian case studies, for instance the General Reading Room of the Klementinum College, mentioned before, or the frame vault of the Broumov Abbey refectory, attributed to K. I. Dientzenhofer by Denti and Skalický (2001), and to understand the widespread of this typology in the Czech Republic.

Thanks to its illusionistic painting, the Klementinum Library offers an interesting connection with the Italian architecture and art, and in particular with the masterpieces of Andrea Pozzo. He worked around Italy, but had a 'northern' cultural background, through the Lombardy painting tradition (Spiriti, 2010). As mentioned before, Hiebel, the painter of the Klementinum Baroque Library, was one of his pupils in Vienna. In the second half of the $17^{\text {th }}$ century, it was common that Bohemian artist travelled to Italy during their artistic training in order to learn the 
painter's profession at art academies or some well-known master's workshop (Fornasiero, 2017). Thanks to Pozzo's travels and the widespread of his pupils all over Europe, it is possible to find the same cupola illusionistic paintings in Italy (Sant'Ignazio church in Rome or Badia delle SS. Flora e Lucilla in Arezzo), in Poland (Cistercians church, Jędrzejów), in Vienna (Universitätskirche) and in Prague (the Klementinum Library) (Salviucci Insolera, 2010).

\section{DATABASE}

The in situ visits, geometrical survey and 3D modeling of the two vaults highlight the richness of solutions adopted in their constructions, the unicity and at the same time the similarities with other vaults within Italy and the Czech Republic.

The construction techniques of such vaulted structures are mostly related to a local building knowledge or described in few treatises. They are also related to the family of workers that travelled over the Alps (Della Torre, 1997). Their 'constructive knowledge' has been mostly unknown to the large public, but now it is possible to study and show it in a wider way, making comparison across time and space, thanks to the use of low cost and fastness surveying techniques, together with GEODB virtual hubs (Brumana et al. 2018b).

\begin{tabular}{|c|c|c|}
\hline & $\begin{array}{l}\text { Klementinum } \\
\text { Baroque Library }\end{array}$ & $\begin{array}{l}\text { Italian Cultural } \\
\text { Institute }\end{array}$ \\
\hline Typology & Skene barrel vault & Skene barrel vault \\
\hline $\begin{array}{l}\text { Sub-typology } \\
\text { (intrados) }\end{array}$ & $\begin{array}{l}\text { Barrel vault with } \\
\text { lunettes }\end{array}$ & Frame vault \\
\hline $\begin{array}{l}\text { Overall } \\
\text { dimension }\end{array}$ & $\begin{array}{c}40 \times 10 \mathrm{~m} \\
\mathrm{H} 7 \mathrm{~m} \\
\end{array}$ & $\begin{array}{c}20.5 \times 6.45 \mathrm{~m} \\
\mathrm{H} 8 \mathrm{~m} \\
\end{array}$ \\
\hline $\begin{array}{l}\text { Construction } \\
\text { period }\end{array}$ & Ended in 1727 & Around the $1660 \mathrm{~s}$ \\
\hline $\begin{array}{l}\text { Stiffening } \\
\text { devices (tie } \\
\text { rods, } \\
\text { extrados } \\
\text { arches,...) } \\
\end{array}$ & $\begin{array}{c}\text { Extrados not } \\
\text { accessible- } \\
\text { probably extrados } \\
\text { arches and tie } \\
\text { rods? } \\
\end{array}$ & $\begin{array}{l}\text { Traces of extrados } \\
\text { arches } \\
2 \text { metal bars } \\
\text { connected the roof } \\
\text { structure to the vault }\end{array}$ \\
\hline Thickness & - & $\begin{array}{c}\text { One layer of bricks, } \\
\text { soldier laid }\end{array}$ \\
\hline \multirow[t]{2}{*}{$\begin{array}{l}\text { Brick } \\
\text { arrangement }\end{array}$} & \multirow[t]{2}{*}{ - } & $\begin{array}{c}\text { Spans no. } 3,4 \\
\text { Barrel vault: soldier } \\
\text { laid bricks } \\
\text { Side barrel vaults: } \\
\text { diagonal bricks } \\
\end{array}$ \\
\hline & & $\begin{array}{c}\text { Spans no. 1,2, } \\
\text { matroneo } \\
\text { Barrel vault: } \\
\text { Diagonal bricks } \\
\text { Side barrel vaults: } \\
\text { Diagonal bricks } \\
\end{array}$ \\
\hline
\end{tabular}

Table 1. First information for the database of the vaults

Virtual Hubs technologies (Mazzetti, et al. 2015) support semantic, geographic and temporal queries on the Open Data (including Geographic Open Data, GOD). They have been used to build a web-accessible platform which is feed by the data gathered during the surveys and the qualitative analysis carried out on the vaulted systems (Brumana et al. 2018b). It is a 'live' updatable repository that can be accessed making different queries, and it allows to manage Geotiff (i.e. the intrados and extrados orthophotos of each vault) related to the geographic coordinates of buildings and to link 3D model objects, together with A360 HBIM free access Autodesk (C). Different information can be uploaded, like the building typology to which the vaults belong, the geographic position (latitude, longitude) of the building, the vaulted typology, the constructive components of the vaulted system, the brick block arrangements with the texturing (soldier laid or in foglio, double or single layered, etc.), the different historical phases, free text description, keywords, together with technical information on the surveying technique, scale and accuracy obtained, as well as diagnostic techniques, like IRT thermal images.

The repository is conceived to be easily used by expert and not experts, making the richness of the acquired data available also to citizens, increasing their awareness on their built heritage.

\section{CONCLUSION}

Although the Klementinum Baroque Library extrados wasn't accessible, the data acquired of the intrados were reliable enough to make some considerations, i.e. the hypothesis of its construction techniques. On the other hand, even the full amount of data of the Italian Cultural Institute was not able to certainly confirm the hypothesis about its construction. In both cases, further analysis has to be undertaken, but these will start from the acquired data and the interpretative 3D models that were realized during this study. The future work can focus on acquiring other valuable data using alternative non-destructive methods, like the laser scanning survey. This will allow to have a robust geometric survey and to better understand decay phenomena (i.e. deflection problems) highlighted by the photogrammetry. Other nondestructive methods such as thermography or ultrasonic testing would be very useful. The thermography can help to recognize the brick arrangement of the vault from the intrados, where the surface is usually covered with plasters and stuccos. At the Italian Cultural Institute, this could be of great help in order to detect the construction techniques of the brackets and the intrados arches of the frame vault. At the Klementinum Baroque Library, this could help to better understand the vault structure and technique. However, in this case, it has to be properly organized since the temperature, and humidity environmental conditions have not to be changed by the instrumental analysis.

Finally, the creation of the databases helps to share the research with other Institutions, increasing the study about Italian-Czech construction techniques connections. Furthermore, it helps to increase the awareness of such richness of information not only among experts and professionals but also among citizens.

\section{ACKNOWLEDGEMENTS}

The research has been supported by institutional support RVO: 68378297 in Czechia.

The authors would like to thank Kateřina Kulawiecová for organizing the visit of Klementinum Baroque Librar y. The cooperation with both organizations, the National Library of the Czech Republic and the Italian Cultural Institute in Prague, is highly appreciated and the authors would like to thank them and their employees for their enthusiastic approach to the research.

\section{REFERENCES}

Banfi, F., 2017. BIM orientation: grades of generation and information for the different type of analysis and management process. In: Int. Arch. Photogramm. Remote Sens. Spatial Inf. Sci, 42(2/W5), pp. 57-64

Banfi, F., Fai, S., Brumana, R., 2017. BIM automation: advanced modeling generative process for complex structures. In: Int. Annals Photogramm. Remote Sens. Spatial Inf. Sci, 4(2-W2), pp. 9-16 
Berger, T., Stirber, P., Záhoř, T., 1999. Restaurátorská Zpráva. Nanebevzetí P. Marie a Sv. Karla Boromejskéhc. Prague: Italian Cultural Institute Library

Brumana, R., Condoleo, P., Grimoldi, A., Landi, A. G., 2017. Shape and construction of brick vaults. Criteria, methods and tools for a possible catalogue. In: Int. Arch. Photogramm. Remote Sens. Spatial Inf. Sci, 42(5/W1), pp. 137-143

Brumana, R., Condoleo, P., Grimoldi, A., Banfi, F., Landi, A. G., Previtali, P., 2018a. HR LOD based HBIM to detect influences on geometry and shape by stereotomic construction techniques of brick vaults. In: Applied Geomatics, 10, pp. 529-543

Brumana, R., Condoleo, P., Grimoldi, A., Landi, A. G, Attico, D., T., Banfi, F., Previtali, M., 2018b. HBIM feeding OpenAccess vault inventory through GeoDB HUB In: Ioannides M. et al., eds., Digital Heritage. Progress in Cultural Heritage. Cham: Springer, pp. 27-38

Della Torre, S., Mannoni, T., Pracchi, V., 1997. Magistri d'Europa. Como: Nodo Libri

Denti, G., Skalický, A., 2001. Paesaggi del barocco boemo. Firenze: Alinea Editrice

Fornasiero, A., 2017. Aspects of artistic training and patronage in Bohemia in the second half of the $17^{\text {th }}$ century. The case of Christian Schröder (1655-1702). PhD dissertation, Charles University

Franchetti Pardo, V., 2002. Un importante capitolo nella storia dell'architettura europea: la cultura rinascimentale, manierista e barocca tra l'Italia e Praga. In: La Nuova Rivista Italiana di Praga, 7(1), pp. 6-27

Graciotti, S., Křesálková, J., 2003. Barocco in Italia, barocco in Boemia. Rome: Il Calamo

Grimoldi, A., 2007. Le catene estradossali come presidio: antiche pratiche e nuove prospettive. In: Sicurezza e conservazione degli edifici storici in funzione delle tipologie edilizie, Milano, 15-17 december 2007, pp. 115-125

Grimoldi, A., 2009. The "frame vaults" of North Italy between the Sixteenth and the Eighteenth century. In: Proceedings of the Third International Congress on Construction History, Cottbus, Maggio 2009, pp. 753-759

Horyna, M., Líbal, D., 1987. I rapporti fra l'architettura italiana e ceca nel corso di un millennio. In: Líbal D., eds., Praga: le forme della città. Rome: Palombi, pp. 21-57

Lipanská, E., 1999. Historické Klenby. Nakladatel: El Consult

Kofroňová, J., 2003. L’Ospedale italiano di Praga: genesi e storia dell'edificio. In: Trezza Cabrales, Angela, La congregazione italiana di Praga: i luoghi e memorie dell'Istituto Italiano di Cultura. Kutná Hora: Tichá Byzanc, pp. 43-58

Mazzetti, P., Latre, M. Á., Ernst, J., Brumana, R., Brauman, S., Nativi, S., 2015. Virtual hubs for facilitating access to open data. In: EGU General Assembly Conference, Vol. 17

Norberg-Schulz, C., 1968. Kilian Ignaz Dientzenhofer e il barocco boemo. Roma: Officina Edizioni
Norberg-Schulz, C., 1982. Architettura tardobarocca. Milan: Electa

Oulíková, P., 2006. The Klementinum: A Guide. Prague: National Library of the Czech Republic, p. 76

Pavlík, M., 1994. Badatelská práce prof. O. Stefana jako výzva pro další generace. In: Sborník př́spěvků k uctěni památky 25. výroči úmrtí prof. Ing. arch. dr. techn. Oldricah Stefana. Prague, pp. 13-26.

Royt, J., 2003. La decorazione pittorica della cappella della Vergine Maria e di S Carlo Borromeo nell'Ospedale italiano. In: Trezza Cabrales, Angela, La congregazione italiana di Praga: $i$ luoghi e memorie dell'Istituto Italiano di Cultura. Kutná Hora: Tichá Byzanc, pp. 57-63

Škabrada, J., 2007. Konstrukce historických staveb. Prague: Argo, p. 395

Salviucci Insolera, L., 2010. Finte prospettive: cupole e soffitti. In: Bösel, R., Salvinucci Insolera, L., eds., Mirabili disinganni. Andrea Pozzo (Trento 1642-Vienna 1709). Pittore e architetto gesuita. Città di Castello: Petruzzi Stampa, pp. 223-225

Spallone, R., Vitali, M., 2017. Volte stellari e planteriane negli atri barocchi in Torino. Canterano: Aracne Editrice

Spiriti, A., 2010. Le radici lombarde dell'attività romana di Andrea Pozzo. In: Bösel, R., Salvinucci Insolera, L., eds., Mirabili disinganni. Andrea Pozzo (Trento 1642-Vienna 1709). Pittore e architetto gesuita. Città di Castello: Petruzzi Stampa, pp. 63-70

Stankova, J., Stursa, J., Vodera, S., 1991. Praga: undici secoli di architettura. Prague: PAV

Stirber, P., Kyncl, J., 1999. Znalecký posudek č. 80-10/99 na dendrochronologické datováni krovu. Prague: Italian Cultural Institute Library

Svorník 5/2007. Klenby. Sborník příspěvků z 5. konference stavebně historického průzkumu uspořádané 6.-9.6. 2006 v Louce u Znojma. Prague: Unicornis

Swoboda, K., M., 1964. Barock in Böhmen. München: Prestel

Swoboda, K., M., 1981. Die grossen meister des 17. Jahrhunderts, Vol. 7. Wien: Verlag Anton Schroll \& Co

Uličný, P., 2014. Albrecht di Wallenstein e gli architetti italiani in Boemia. In: Bollettino dell'Istituto Storico Ceco di Roma, 9, pp. 273-284

Vinař, J., 2010. Historické krovy - typologie, průzkum, opravy. Prague: Grada, p. 448

Wendland, D., 2005. Volte in laterizio: aspetti costruttivi della tecnica tradizionale. In: Costruire in laterizio, 107, pp. 55-59 